Journal of

Accident and Emergency Medicine 1995

$12,40-42$

\title{
Violence towards junior doctors in accident and emergency departments
}

\author{
J.P.WYATT \& M. WATT \\ Department of Accident and Emergency, Western Infirmary, Glasgow
}

\section{SUMMARY}

The experience and training of accident and emergency (A\&E) junior doctors with regard to patient aggression was investigated by use of a telephone questionnaire. A total of 114 A\&E departments in five different regions in the United Kingdom were telephoned. A total of 100 junior doctors answered the questionnaire. Verbal aggression had been experienced by 96 of them, 50 had received threats and 32 said that patients had tried to assault them. Eighteen doctors had been assaulted by patients on a total of 23 occasions. Thirty-two doctors admitted that they had been upset after a violent incident, so much so that they were preoccupied with it after work. None of those assaulted received any counselling and no police charges resulted from the assaults. Only 11 doctors had received any training on how to manage aggressive patients, although 88 believed that it would be useful.

The results of this study indicate that violence towards junior doctors in A\&E is a significant problem. Aspects of this problem, including training and support for staff, need to be addressed urgently.

Key words: violence

\section{INTRODUCTION}

Doctors are often exposed to extremes of patient behaviour, including aggression. This aggression may result from a variety of underlying medical disorders, such as hypoglycaemia, requiring prompt diagnosis and treatment. Staff facing violent patients have the added worry that attacks on doctors may have serious, sometimes fatal, results. ${ }^{1}$

Patient aggression is recognized to be a significant problem in the emergency departments of the United States. ${ }^{2}$ Some US hospitals employ routine weapon screening of patients using metal detectors, and staff receive training in the management of the aggressive patient. ${ }^{3,4}$ In 1987 the UK Health and Safety Commission report identified violence directed towards staff working in A\&E departments as a particular problem and made recommendations concerning training and support for staff. ${ }^{5}$ This study was undertaken to investigate the scale and management of patient aggression directed towards junior A\&E doctors, with special reference to these recommendations.

\section{METHODS}

All the A\&E departments in five different regions of the country (South-East England, South-West England, Yorkshire, Wales and Scotland) were telephoned and a request was made to speak to a senior house officer (SHO). A single questioner asked the first available A\&E SHO a series of standardized questions about any aggressive patients that they had had experience in their current post and the training that they had received to deal with it. One SHO in each hospital was questioned.

\section{RESULTS}

A total of 114 A\&E departments were contacted by telephone. In 14 departments there was either no SHO on duty (the department being staffed by other grades of doctor) or the SHO was too busy to come to the telephone. All 100 SHO's who were able to come to the telephone agreed to answer the study questions. Eighty-eight of these SHOs had been working in their current post for 4 months. The questions asked and answers given by the 100 SHOs are shown in Table 1. SHOs who admitted to experiencing various forms of aggression or reactions to it were also asked how often it happened to them.

Further details were obtained about the assaults. A total of 18 SHOs reported 23 assaults. Thankfully, no doctor suffered permanent physical damage as a result. None of those assaulted were given counselling. No police charges followed any of the assaults. Four patients who displayed aggression towards the SHOs were charged by police and caused damage to hospital property.

(C) 1995 Blackwell Science Ltd 
Violence towards junior doctors
Standard questions asked of 100 SHOs about their current post (followed, where appropriate, by the question: how often, on average, does this happen?)
Number reporting frequency of event more than once per week
Table 1. Results of the questionnaire

\begin{tabular}{|c|c|c|}
\hline Has a patient sworn at you? & 96 & 66 \\
\hline Has a patient threatened to hurt you? & 50 & 1 \\
\hline Has a patient tried to assault you? & 32 & 0 \\
\hline Has a patient assaulted you? & 18 & 0 \\
\hline $\begin{array}{l}\text { Have you been concerned for your } \\
\text { own personal safety when dealing } \\
\text { with an aggressive patient? }\end{array}$ & 41 & 4 \\
\hline $\begin{array}{l}\text { Have you been upset about an } \\
\text { aggressive incident so that you were } \\
\text { preoccupied with it after work? }\end{array}$ & 32 & 2 \\
\hline $\begin{array}{l}\text { Have police charged any patient } \\
\text { following aggression towards you? }\end{array}$ & 4 & 0 \\
\hline $\begin{array}{l}\text { Have you received any training } \\
\text { on managing aggression in your } \\
\text { current job? }\end{array}$ & 11 & - \\
\hline $\begin{array}{l}\text { Do you believe that it is useful to teach } \\
\text { A\&E SHOs how to manage } \\
\text { aggression? }\end{array}$ & 88 & - \\
\hline
\end{tabular}

\section{DISCUSSION}

This study has revealed that SHOs in A\&E departments have been exposed frequently to patient aggression. The most common form was verbal abuse, which the majority of SHOs reported experiencing on a weekly basis. However, on occasions the aggression amounted to physical violence. Many SHOs admitted that they had been worried about their own personal safety and upset by their experiences. The A\&E department is clearly, at times, a hostile environment for junior medical staff. The fact that 23 assaults took place is cause for particular concern. The lack of charges and subsequent support for those assaulted, suggests that the police and hospital authorities are either ignorant of, or are reluctant to take seriously, the problem of violence to hospital staff. It is disappointing that Health and Safety Commission recommendations regarding training and support for doctors involved in violent incidents do not appear to have been implemented in the A\&E departments studied. ${ }^{5} A$ recent survey amongst $A \& E$ nurses also revealed that the majority had not received training on managing patient aggression. ${ }^{6}$ These issues need to be addressed urgently. teaching in dealing with aggressive behaviour. Training in managing aggression has certainly been shown to prevent and limit potentially explosive situations. ${ }^{7}$ Once restraint is required, the patient, staff and even innocent bystanders are at risk of injury. ${ }^{8}$ Training may help to reduce this risk. Such training currently appears to be lacking in the United Kingdom - consideration should be given to this when introducing junior doctors to A\&E.

\section{REFERENCES}

1. Anon (1978) Assaults on doctors. British Medical Journal 6122, 1229-1230.

2. Pane G.A., Winiarski A.M. \& Salness K.A. (1991) Aggression directed toward emergency department staff at a university teaching hospital. Annals of Emergency Medicine 20, 283-286.

3. Lavoie F.W., Carter G.L., Danzl D.F. \& Berg R.L. (1988) Emergency department violence in United States teaching hospitals. Annals of Emergency Medicine 17, 1227-1233.

4. Thompson B.M., Nunn J., Kramer T., Timmins I. \& Tomlanovich M. (1988) Disarming the department weapon screening and improved security to create a safer ED environment. Annals of Emergency Medicine $17,419$. 
J.P. Wyatt \& $M$.

Watt
5. Health and Safety Commission. (1987) Violence to staff in the health services. London.

6. Schnieden V. \& Marren-Bell U. (1992) Violence in the accident and emergency department. Archives of Emergency Medicine 9, 330-331.

7. Infantino J.A. \& Musingo S.Y. (1985) Assaults and injuries among staff with and without training in aggression control techniques. Hospital and Community Psychiatry 36, 1312-1314.

8. Wasserberg J., Ordog G.J., Kolodny M. \& Allen K. (1989) Violence in a community emergency room. Archives of Emergency Medicine 6, 266-269. 